\title{
The Application of Computer Techniques to the Taxonomy of the Root-nodule Bacteria of Legumes
}

\author{
By P. H. GRAHAM* \\ Department of Soil Science and Plant Nutrition, \\ Institute of Agriculture, University of Western Australia
}

(Received 25 February 1964)

\begin{abstract}
SUMMARY
The application of computer techniques to study a group of organisms comprising 83 strains of the genus Rhizobium and 38 strains belonging to the genera Agrobacterium, Chromobacterium, Beijerinckia and Bacillus is described. One hundred different features including vitamin, carbohydrate and nitrogen nutrition, antibiotic sensitivities, morphological and colonial characteristics, and infective attributes were used to determine the relationships between these organisms. Members of the genera Chromobacterium, Bacillus and Beijerinckia showed little affinity with the other species studied, or with each other. The results obtained for the genus Rhizobium indicate the need for major taxonomic changes. These changes would include: (1) the consolidation of $R$. trifolii, $R$. leguminosarum and $R$. phaseoli into a single species, $R$. leguminosarum; (2) The consolidation of $\boldsymbol{A}$. radiobacter and A. tumefaciens and their inclusion as $\boldsymbol{R}$. radiobacter in the genus Rhizobium. The creation of a new genus Phytomyxa to contain strains of slow-growing root-nodule bacteria is also proposed.
\end{abstract}

\section{INTRODUCTION}

Studies begun at this Institute in 1957 considered the infective properties of root-nodule bacteria isolated from leguminous plants indigenous to the southwestern portion of Western Australia. Of 85 isolates of these bacteria examined, 45 nodulated hosts in each of the lupin, soybean, phaseolus and cowpea cross-inoculation groups, and 31 nodulated hosts in three of these groups. Only three strains could be classified on the basis of their infective properties. In reporting on these experiments Lange $(1960,1961)$ suggested a programme for the study and application of computer techniques to the classification of a representative sample of rootnodule bacteria. The present investigation was undertaken as an extension of Lange's work, and reports a study of rhizobial taxonomy based on the use of the computer methods he suggested.

\section{METHODS}

Organisms. A total of 121 isolates were used in this study. The species represented were Rhizobium trifolii (19 strains), R. leguminosarum (13), R. phaseoli (5), $\boldsymbol{R}$. meliloti (11), R. lupini (10), R. japonicum (6), Rhizobium spp. (19), Agrobacterium radiobacter (7), A. tumefaciens (11), Beijerinckia indica (8), Chromobacterium violaceum (6) and Bacillus polymyxa (5). Rhizobial strains were selected for host

* Present address: Faculty of Agriculture, University of Sydney, Sydney, N.S.W. 
differences and for geographical diversity. They included isolates from Arachis, Astragalus, Boisseae, Cajanus, Cicer, Crotalaria, Desmodium, Dorycnium, Glycine (3 species), Jacksonia, Kennydiya, Lathyrus (3 species), Lotononis, Lotus (2 species), Lupinus (5 species), Medicago (6 species), Oxylobium, Phaseolus (3 species), Pisum (3 species), Psoralea, Sesbania, Trifolium (11 species), Vicia (3 species), Vigna and Wistaria. Isolates were obtained from Australia (41 strains), Canada (1 strain), Germany (4 strains), Japan (7 strains), Kenya (8 strains), South Africa (8 strains), South America (3 strains), Tanganyika (3 strains), U.K. (3 strains) and U.S.A. (5 strains). The non-rhizobial organisms were included because of earlier claims relating them to rhizobia (Bonnier, 1953; Derx, 1953; Bissett, 1959).

Maintenance of organisms. Organisms were preserved where necessary by lyophilization (Annear, 1956) and stored in the cold at $4^{\circ}$. Organisms were cultivated routinely on a yeast extract mannitol medium or on potato dextrose agar, and were checked for purity at least once every 6 weeks.

Features. Each of the 121 organisms was characterized by its reaction to 100 different tests. The features considered were: reduction of methylene blue; production of levan; acid reaction in litmus milk, serum zone in litmus milk, coagulation of litmus milk; methyl red test; Voges-Proskauer reaction; precipitation in calcium glycerophosphate medium; production of indole; hydrolysis of gelatin; anaerobic growth; growth at $4^{\circ}$, growth at $39^{\circ}$; growth at $\mathrm{pH} 3 \cdot 5,4 \cdot 0,4 \cdot 5,5 \cdot 0,8 \cdot 0,8 \cdot 5,9 \cdot 0$, 9.5; colonies circular; colonies convex; colony margin entire; colony size less than $3 \mathrm{~mm}$., after 7 days' incubation; colony size less than $1 \mathrm{~mm}$.; pigment produced; butyrous gum produced; growth on sodium citrate agar; urea hydrolysed; catalase produced; oxidase produced; growth on nitrogen-free mineral media; nitrate reduced, nitrite reduced; biotin essential for growth; thiamine essential for growth, calcium pantothenate essential for growth; growth on $2 \% \mathrm{NaCl}$ medium, growth on $\mathbf{3} \% \mathrm{NaCl}$ medium; utilization of dextrin, maltose, lactose, rhamnose, glucose, sucrose, mannitol, starch, galactose, sorbitol, dulcitol, inulin, raffinose, arabinose and xylose; nodulation Trifolium subterraneum L., T. repens L., Lupinus digitatus Forsk., Medicago sativa L., M. tribuloides Desr., Ornithopus sativus Brot., Pisum sativum L., Vicia sativa L., Glycine max Merr., Vigna sinensis Engl., Phaseolus lathyroides $\mathbf{L}$. and $\boldsymbol{P}$. vulgaris $\mathbf{L}$.; gall formation on tomato seedlings; cells rod shaped; width of cells greater than $1.25 \mu$, length of cells less than $2.5 \mu$, length of cells less than $4 \cdot 0 \mu$; spores produced; metachromatic granules produced; cells Gram positive; cells motile; gas produced in fermentation media; sensitivity to streptomycin, aureomycin, terramycin, ledermycin, neomycin, chloramphenicol, penicillin, bacitracin and erythromycin (each antibiotic tested at $0 \cdot 1,4 \cdot 0$ and $50 \mu \mathrm{g}$./ sensitivity disc); hydrogen cyanide produced; survival after $10 \mathrm{~min}$. heating at $50^{\circ}$. Where possible the methods used were those recommended by the American Society of Bacteriologists (1957). Other methods have been detailed by Graham (1963a,b, $c$; Graham, to be published).

Computer analysis. The computer analysis was carried out on an IBM 1620 digital computer, with a programme which differed from that of Sneath (1957) in that negative matches were scored as similarities. Quantitative tests were minimized because of differences in the growth rates of the strains studied. Where quantitative results were used, they were scored by the additive method of Sneath (1962). Similarity values (S) were printed by successive $1 \%$ decreases in value. 


\section{RESULTS}

The results of the computer analysis are presented in Fig. 1. The main features are as follows.

(1) Strains of Bacillus polymyxa, Chromobacterium violaceum and Beijerinckia indica showed low affinities with the root-nodule bacteria. Few comparisons between these organisms and rhizobial strains exceeded $70 \%$ similarity. Comparisons between strains of Rhizobium and $\boldsymbol{B}$. polymyxa rarely exceeded $50 \%$ similarity.

(2) Strains of Agrobacterium radiobacter and $A$. tumefaciens grouped with the fastgrowing strains of Rhizobium, especially with strains of $R$. meliloti. All comparisons between the two Agrobacterium species exceeded $80 \% \mathrm{~S}$, and values greater than $90 \%$ were common. Strains of $\boldsymbol{R}$. meliloti grouped with these species at a somewhat lower value, but with most comparisons exceeding $80 \%$ similarity. All three species showed similarities greater than $70 \% \mathrm{~S}$ with strains of $\boldsymbol{R}$. leguminosarum, $\boldsymbol{R}$. phaseoli and $\boldsymbol{R}$. trifolii but only a 50-60\% similarity with the strains of slowgrowing rhizobia.

(3) With the exception of Rhizobium phaseoli strain 88, all strains of $R$. leguminosarum, $R$. trifolii and $R$. phaseoli grouped together with similarity values in the range $80-97 \%$. Strains within this group were commonly less related to the slowgrowing group of rhizobia than they were to strains of Beijerinckia indica and Chromobacterium violaceum. Eight South African clover rhizobia included in this group showed high affinities with clover and pea rhizobia of European origin.

(4) Strains of slow-growing rhizobia formed a third group of organisms, with similarities in the range 70-95\%. Rhizobium phaseoli strain 88 appeared to fit more naturally into this group than into the rhizobia of the $R$. leguminosarum type.

(5) A distinct division in the strains listed as Rhizobium spp. was evident, with seven strains grouping with the fast-growing rather than with the slow-growing group of organisms. Two of these strains $(102,110)$ appeared to have a legitimate relationship to the rhizobia of the $R$. leguminosarum type; both strains nodulated Pisum sativum. The remaining strains, and $\boldsymbol{R}$. japonicum strain 91, must be regarded as nodule contaminants of the Agrobacterium radiobacter type.

\section{DISCUSSION}

Similarity values obtained from a computer survey may be related to taxonomic rank, but, since the number and variety of tests used may vary, no absolute criterion can be set for the different taxonomic levels. The similarity values obtained in this study were, in general, higher than those reported for similar groups of organisms (Sneath, 1957; Talbot \& Sneath, 1960). This was due to the inclusion of all nodulation data in the analysis, and to the limited use of quantitative coding.

The results obtained in this investigation indicate the need for taxonomic change in the genus Rhizobium. Strains of $\boldsymbol{R}$. leguminosarum, $\boldsymbol{R}$. trifolii and $\boldsymbol{R}$. phaseoli formed a homogeneous and indivisible group with similarity values of 80-97\% $\mathrm{S}$ occurring within the group. They should therefore be considered as a single species. As this group of organisms contains strains capable of nodulating Lathyrus, it must continue as the type species of the family Rhizobiaceae, and bear the name $R$. leguminosarum Frank. Since comparisons between $A$. radiobacter, $A$. tumefaciens and 
the organisms of the $R$. leguminosarum type always exceeded $70 \%$ similarity the inclusion of these non-nodule-forming organisms in the genus Rhizobium appears warranted. Although these two groups appear to merge into one another, differences between the groups are sufficient to warrant separation at the specific level. Strains of $\boldsymbol{R}$. meliloti, $\boldsymbol{A}$. radiobacter and $\boldsymbol{A}$. tumefaciens were very closely related and on the evidence presented in this paper should be considered a single species. In view of the small sample size, however, it is perhaps better to suggest the consolidation of $A$. radiobacter and $A$. tumefaciens, and their inclusion as Rhizobium radiobacter (Beijerinck and van Delden) in the genus Rhizobium, with the retention of $\boldsymbol{R}$. meliloti as a separate species within this genus. Further experimentation could confirm the relationship between these organisms.

Strains of Rhizobium lupini, $R$. japonicum and Rhizobium spp. grouped at the 70-90 \% values but showed very low affinities with the fast-growing species. The consolidation of these three species and their separation from the fast-growing rhizobia at the generic level appears warranted. However, since the sample of strains used is small in relation to the probable size of the group it represents, this separation must first be confirmed by additional studies with more representative strains. If these investigations confirm the need for separation at the generic level, the genus containing the slow-growing group of organisms should bear the name Phytomyxa and the type species be termed Phytomyxa japonicum Kirchner. The generic name Phytomyxa was proposed by Schroeter in 1886 and was suggested by Buchanan (1926) as an alternative title to Rhizobium. Kirchner (1895) proposed the name Rhizobacterium japonicum for the nodule organism of soybean.

The suggested changes may be summarized as:

$\begin{array}{ll}\text { Genus } & \text { Rhizobium } \\ \text { Type species } & \text { Rhizobium leguminosarum Frank } \\ \text { Species } & \text { (1) R. leguminosarum Frank } \\ & \text { (2) R. meliloti Dangeard } \\ & \text { (3) R. radiobacter (Beijerinck and van Delden) Löhnis } \\ \text { Genus } & \text { Phytomyxa } \\ \text { Type species } & \text { Phytomyxa japonicum Kirchner }\end{array}$

The proposed changes are strongly supported by infective data and by other evidence in the literature. Many similarities between strains of Rhizobium leguminosarum, $\boldsymbol{R}$. trifolii and $\boldsymbol{R}$. phaseoli have been shown before; Smith (1958) and Ishizawa (1953 $a, b, c)$ showed morphological and biochemical similarities between these species. Serological affinities and phage relationships between the species have also been reported (Kleczkowska, Nutman \& Bond, 1944; Conn, Bottcher \& Randall, 1945; Kowalski \& Staniewski, 1959; Graham, 1963c). Infective relationships have been shown by Kleczkowski \& Thornton (1944), Wilson (1939, 1944), Norris (1959) and Graham (1963c). Thus the results of the present analysis confirm a grouping already apparent from more conventional taxonomic studies.

The affinities of the different species of slow-growing root-nodule bacteria are also apparent from other studies. Lange (1961), for example, showed that 76 strains out of a total of 85 considered would nodulate hosts in three or more of the phaseolus, lupin, soybean and cowpea cross-inoculation groups. Similar results were obtained by Bushnell \& Sarles (1937) and Wilson $(1939,1944)$. The consolidation of Rhizobium japonicum and the cowpea rhizobia was first suggested by Walker \& Brown (1935). 
Biochemical similarities (Smith, 1958) and serological similarities (Bushnell \& Sarles, 1939) have also been reported.

Serological and biochemical affinities between Agrobacterium radiobacter, $\boldsymbol{A}$. tumefaciens and Rhizobium meliloti have been reported before (Hofer, 1941; Coleman \& Read, 1945; Manil \& Bonnier, 1950; Bonnier, 1953). More recently, Roslycky, Allen \& McCoy (1962) have reported phages lytic for species of $A$. radiobacter, A.tumefaciens, R. meliloti, and R. trifolii. Both Pribram (1933) and Bonnier (1953) suggested the inclusion of $A$. radiobacter and $A$. tumefaciens in the genus Rhizobium.

Despite existing results in support of the evidence presented here, some caution is necessary. The rhizobia considered in this survey were derived from 27 genera and 40 species of leguminous plants; more than 500 genera and 12,000 species and their associated nodule bacteria remain to be studied. The tendency, following Norris (1956), is to regard all such organisms as similar to the cowpea type of organism. Two of the strains considered in this survey, isolated from hosts normally included in the cowpea cross-inoculation group, closely resembled the rhizobia of the Rhizobium leguminosarum type; other fast-growing forms may be found. The effect of the withdrawal of the type species from the genus Agrobacterium must also be considered. Despite these difficulties, the proposed classification appears to be more logical than the present agronomically biased one. An additional advantage is that this method of classification is not influenced by the loss of infective properties.

Numerical taxonomy has been suggested as a means of determining the ancestry of organisms (Sneath \& Sokal, 1962). Norris (1956) postulated that the root-nodule bacteria had evolved from an organism similar to the present-day slow-growing type, and suggested that the change from slow-growing to fast-growing type resulted from the recession of the post-Permian seas and the exposure of rich calcareous soils. The results obtained here suggest differences too great to be explained in terms of such evolutionary differentiation. Considering the many nitrogen-fixing symbioses known, and the decisive differences shown by this survey, it is more logical to suggest the evolution of two different soil organisms to symbiosis with leguminous plants. Despite the claims of other workers (Bissett, 1952, 1959; Derx, 1953), it seems unlikely that the rhizobia evolved from organisms closely related to Bacillus polymyxa, Chromobacterium violaceum or Beijerinckia indica. The origin of the slow-growing nodule strains remains obscure, but the results obtained here would suggest a form similar to Agrobacterium radiobacter or $A$. tumefaciens as the ancestor of the fast-growing rhizobia and an evolutionary pathway leading from these organisms to organisms of the R. meliloti and R. leguminosarum types. Aspects of this relationship will be considered in a subsequent paper.

I am particularly indebted to Dr C. A. Parker for constant help and encouragement, to $\mathrm{Mr} \mathrm{S}$. R. Hall for his assistance in the planning of the computer programme, and to Miss M. Jones and Mr D. Brocx for careful technical assistance. For financial support I am grateful for the award of the Bank of New South Wales Research Fellowship in Agriculture, and for research grants from the University of Western Australia. Grateful acknowledgeent is also made to Professor E. J. Underwood, Director of the Institute, for the opportunity to carry out this research. 


\section{REFERENCES}

American Society for Bacteriologists (1957). Manual of Microbial Methods. New York: McGraw Hill.

Annear, D. I. (1956). Freeze drying. III. The preservation of bacteria. Lab. Pract. p. 102.

BissetT, K. A. (1952). Observations on the morphology and natural relationships of Rhizobium. J. gen. Microbiol. 6, i.

Bissett, K. A. (1959). Some characters of Rhizobium strains from tropical legumes. J. gen. Microbiol. 20, 89.

Bonnier, C. (1953). Classification et spécificité de l'hôte dans le genre Rhizobium. Proc. 6th int. Congr. Microbiol. 6, 325.

Buchanan, R. E. (1926). What names should be used for the organisms producing nodules on the roots of leguminous plants? Proc. Acad. Sci. 33, 81.

Bushnell, O. A. \& Sarles, W. B. (1937). Studies on the root nodule bacteria of wild leguminous plants in Wisconsin. Soil Sci. 44, 409.

Bushnell, O. A. \& Sarles, W. B. (1939). Investigation upon the antigenic relationships among the root-nodule bacteria of the soybean, cowpea, and lupin cross-inoculation groups. J. Bact. 38, 401.

Coleman, M. F. \& REaD, J. J. (1945). A serological study of strains of Alcaligenes radiobacter and Phytomonas tumefaciens in the $M$ and $S$ phases. J. Bact. 49, 187.

Conn, H. J., BotTcher, E. R. \& Randall, C. (1945). The value of bacteriophage in classifying certain soil bacteria. J. Bact. 49, 359.

Derx, H. G. (1953). Sur les causes de la distribution géographique limitée des Beijerinckia. Proc. 6th int. Congr. Microbiol. 6, 354.

Graham, P. H. (1963a). Vitamin requirements of the root-nodule bacteria. J. gen. Microbiol. 30, 245.

Graham, P. H. (1963b). Antibiotic sensitivities of the root-nodule bacteria. Aust. J. biol. Sci. 16, 557.

Graham, P. H. $(1963 c)$. A study on the application of sero-diagnostic and computative methods to the taxomomy of the root-nodule bacteria of legumes. Ph. D. thesis. University of Western Australia.

Hofer, A. W. (1941). A characterisation of Bacterium radiobacter (Beijerinck and Van Delden) Löhnis. J. Bact. 41, 193.

Ishizawa, S. $(1953 a)$. Studies on the root nodule bacteria of leguminous plants. I. Characters in artificial media. Part I. Morphology. J. Sci. Soil, Tokyo, 23, 125.

Ishizawa, S. $(1953 b)$. Studies on the root nodule bacteria of leguminous plants. I. Characters in artificial media. Part $3 f$. Carbon source (growth and fermentation). J. Sci. Soil, Tokyo, 23, 163.

Ishizawa, S. $(1953 \mathrm{c})$. Studies on the root nodule bacteria of leguminous plants. Part 4. The effect of $\mathrm{pH}$ on the growth of rhizobia. J. Sci. Soil, Tokyo, 23, 169.

Kirchner, O. (1895). Die Wurzellknöllchen der Sojabohne. Beitr. Biol. Pfl. 7, 213.

Kleczkowska, J., Nutman, P.S. \& Bond, G. (1944). Note on the ability of certain strains of rhizobia from peas and clover to infect each other's host plants. J. Bact. 48, 673.

Kueczkowski, A. \& Thornton, H. G. (1944). A serological study of the root nodule bacteria from the pea and clover inoculation groups. J. Bact. 48, 661 .

Kowalski, M. \& Staniewski, R. (1959). Preliminary investigations on the susceptibility of different strains of Rhizobium to phages. Acta microbiol. polon. 8, 253.

Lange, R. T. (1960). Rhizobium of South Western Australia. Ph.D. thesis. University of Western Australia.

LANGE, R. T. (1961). Nodule bacteria associated with the indigenous Leguminosae of South-Western Australia. J. gen. Microbiol. 26, 351.

Manil, P. \& Bonnier, C. (1950). Fixation symbiotique d'azote chez la luzerne (Medicago sativa). Bull. Inst. agron. Gembloux, 18, 89.

Norris, D. O. (1956). Legumes and the Rhizobium symbiosis. Emp. J. exp. Agric. 24, 247. 
Norris, D. O. (1959). Legume bacteriology in the tropics. J. Aust. Inst. agric. Sci. 25, 202.

Pribram, E. (1933). Klassifikation der Schizomyceten. Leipzig und Wien: Deuticke.

Roslycky, E. B., Allen, O. N. \& McCoy, E. (1962). Phages for Agrobacterium radiobacter with reference to host range. Canad. J. Microbiol. 8, 71.

Schroeter, J. (1886). Die Pilze Schlesiens. Cohn's Kryptogamen Flora von Schlesien Bog. 9, 135.

Smith, K. N. (1958). Bacteriology of the genus Rhizobium. In Nutrition of Legumes, 5th Nottingham Easter Conf. London: Butterworth.

SNeATh, P. H. A. (1957). The application of computers to taxonomy. J. gen. Microbiol. 17, 201.

SNEath, P. H. A. (1962). The construction of taxonomic groups. In Microbial Classification. Symp. Soc. gen. Microbiol. 12, 289.

SNeath, P. H. A. \& Sokal, R. R. (1962). Numerical taxonomy. Nature, Lond. 193, 855.

'Talbot, J. M. \& Sneath, P. H. A. (1960). A taxonomic study of Pasteurella septica, especially of strains isolated from human sources. J. gen. Microbiol. 22, 303.

WALKer, R. H. \& Brown, P. E. (1935). The nomenclature of the cowpea group of root nodule bacteria. Soil Sci. 39, 221.

Wilson, J. K. (1939). Symbiotic promiscuity in the Leguminosae. 3rd int. Soil Sci. Soc. Trans. A, p. 49.

Wilson, J. K. (1944). Over five hundred reasons for abandoning the cross inoculation groups of legumes. Soil Sci. 58, 61. 